University of Nebraska - Lincoln

DigitalCommons@University of Nebraska - Lincoln

Faculty Publications: Department of

Entomology

Entomology, Department of

2000

Comparison of $\mathrm{Bt}$ (Bacillus thuringiensis Berliner) Maize and

Conventional Measures for Control of the European Corn Borer (Lepidoptera: Crambidae)

\author{
Thomas L. Clark \\ University of Nebraska-Lincoln \\ J. E. Foster \\ University of Nebraska-Lincoln, john.foster@unl.edu \\ Shripat T. Kamble \\ Universitiy of Nebraska-Lincoln, skamble1@unl.edu \\ Elvis A. Heinrichs \\ University of Nebraska - Lincoln, eheinrichs2@unl.edu
}

Follow this and additional works at: https://digitalcommons.unl.edu/entomologyfacpub

Part of the Entomology Commons

Clark, Thomas L.; Foster, J. E.; Kamble, Shripat T.; and Heinrichs, Elvis A., "Comparison of Bt (Bacillus thuringiensis Berliner) Maize and Conventional Measures for Control of the European Corn Borer (Lepidoptera: Crambidae)" (2000). Faculty Publications: Department of Entomology. 918.

https://digitalcommons.unl.edu/entomologyfacpub/918

This Article is brought to you for free and open access by the Entomology, Department of at DigitalCommons@University of Nebraska - Lincoln. It has been accepted for inclusion in Faculty Publications: Department of Entomology by an authorized administrator of DigitalCommons@University of Nebraska - Lincoln. 


\title{
Comparison of Bt (Bacillus thuringiensis Berliner) Maize and Conventional Measures for Control of the European Corn Borer (Lepidoptera: Crambidae) ${ }^{1}$
}

\author{
Thomas L. Clark, J. E. Foster, Shripat T. Kamble and E. A. Heinrichs \\ Department of Entomology, University of Nebraska-Lincoln Lincoln, NE 68583-0816 USA
}

\begin{abstract}
J. Entomol. Sci. 35(2): 118-128 (April 2000)
Abstract Field experiments were conducted in 1997 to compare the efficacy Bt (Bacillus thuringiensis Berliner) maize hybrids and two conventional measures for control of the European corn borer, Ostrinia nubilalis (Hübner). Treatments consisted of transgenic Bt maize hybrids and their non-Bt isolines, and isolines treated with a formulated $B t$ or permethrin insecticide. All control measures significantly reduced $O$. nubilalis damage in terms of tunnels per plant, length of tunneling, and larvae per plant. The following hierarchy in terms of $O$. nubilalis efficacy was observed: transgenic $B t>$ permethrin > formulated $B t>$ control. In most cases, transgenic $B t$ maize was most effective in preventing European corn borer damage to ear shanks and generally produced the highest grain yields.
\end{abstract}

Key Words European corn borer, transgenic maize, permethrin, formulated Bt, maize, Bacillus thuringiensis

The European corn borer, Ostrinia nubilalis Hübner, is a major pest of maize, Zea mays (L.), in the United States. In terms of control costs and yield loss, damage by this insect costs maize farmers more than $\$ 1$ billion annually (Mason et al. 1996). Annual losses in Nebraska are estimated at \$48 million (Bullock and Sollod 1996). First-generation European corn borer damage is generally characterized by leaf and midrib feeding and stalk tunneling. Second-generation damage is characterized by stalk tunneling, leaf sheath feeding, collar feeding, and ear damage. European corn borer feeding often results in physiological (reduced ear development) and physical (broken stalks and dropped ears) damage that may significantly reduce grain yield.

Historically, $O$. nubilalis has been controlled using resistant maize varieties, biological agents, and insecticide spray programs. Recent commercial release of transgenic maize hybrids with the $B t$ (Bacillus thuringiensis Berliner) gene offers maize producers a new technology to control maize pests. In the USA, hectares of genetically-enhanced maize, including maize with the $B t$ gene, increased from 0.16 million ha in 1996 to 6.90 million ha (21\% of maize area) in 1998 (Tally 1998). The insecticidal protein or delta-endotoxin in transgenic maize provides control of several lepidopteran species. In the USA, Williams et al. (1998) reported on the adverse effects of the $B t$ insecticidal protein in transgenic maize on the fall armyworm, Spodoptera frugiperda (J. E. Smith), southwestern corn borer, Diatraea grandiosella (Dyar), and the corn earworm, Helicoverpa zea (Boddie). Data from other field studies have

\footnotetext{
'Received 09 April 1999; accepted for publication 11 July 1999.
} 
demonstrated the efficacy of transgenic maize for $O$. nubilalis control, which encodes insect-specific toxic proteins (Koziel et al. 1993). Transgenic maize expressing the $B t$ delta-endotoxin is also a promising means of maize borer management in tropical production systems (Bergvinson et al. 1997).

Commercial release of $B t$ maize has to some extent replaced the use of insecticides for $O$. nubilalis control. Traditional insecticide spray programs commonly provide $80 \%$ and $67 \%$ control of first and second generation $O$. nubilalis, respectively (Ostlie et al. 1997). Among the current insecticides recommended for first-generation $O$. nubilalis control in Nebraska are spray applications of $B$. thuringiensis and permethrin. Permethrin is also recommended for control of the second-generation (Wright et al. 1994).

To increase the effectiveness of formulated $B t$ in $O$. nubilalis control it has been used in combination with other insecticides such as permethrin. Permethrin is effective for control of $O$. nubilalis larvae and also provides ovicidal activity (Rinkleff et al. 1995). However, at full rates permethrin adversely affects predator populations (Bolin et al. 1996). Ayyappath et al. (1996) reported resurgence of two-spotted spider mites, Tetranychus urticae Koch, when permethrin was applied for $O$. nubilalis control in Nebraska tests. Thus, lower rates of permethrin plus Dipel ${ }^{\mathrm{TM}}$ (Abbott Lab., N. Chicago, IL) have been tested, and the combination provides control equal to full rates of permethrin (Bartels and Hutchison 1995).

Another approach to increase the effectiveness of $B$. thuringiensis against the $O$. nubilalis has been to integrate it with host plant resistance. In the control of the $O$. nubilalis on sweet corn, resistant hybrids sprayed with $B$. thuringiensis provided a viable alternative to an insecticide-based (permethrin) management strategy in the upper midwestern USA (Bolin et al. 1996). Resistant hybrids + B. thuringiensis provided $95 \%$ control of late-instar $O$. nubilalis larvae in the ear which was equal to the control provided by a susceptible hybrid + permethrin.

Preliminary studies conducted in Nebraska indicate that selected Bt maize hybrids provide approximately $99 \%$ control for first-generation and 70 to $99 \%$ control for second-generation $O$. nubilalis (Clark and Foster, unpubl. data). The purpose of this study was to compare the effectiveness of $B t$ maize hybrids with recommended conventional insecticides in the control of first- and second-generation $O$. nubilalis larvae.

\section{Materials and Methods}

This study was conducted in 1997 at single locations in Dixon and Saunders counties, NE. The Dixon Co. site (planted 15 May 1997) was at the University of Nebraska, Haskell Agricultural Laboratory, Concord, NE, and the Saunders Co. site (planted 23 May 1997) was at the University of Nebraska, Agricultural Research and Development Center, Ithaca, NE.

Three maize hybrids that had $B t$ events and their non-Bt near isolines that were developed for local growing conditions were used at each study site. At Dixon Co., the non-transgenic isolines and $B t$ transgenic hybrids planted were: DEKALB 580 and DEKALB 580Bt (Event DBT-418), Novartis 4640 and Novartis $4640 B t$ (Event Bt11), and Mycogen 5250 and Mycogen 2598Bt (Event 176). At Saunders Co. the hybrids planted were: DEKALB 580 and DEKALB $580 B t$, Novartis 7070 and Novartis $7070 B t$, (Event Bt11), and Mycogen 7050 and Mycogen 7059Bt (Event 176). All Bt events have unique properties (Caprio et al. 1999). The DBT-418 event codes for the Cry1AC 
protein with the e-35S promoter (DEKALB Genetics Corp., DeKalb, IL). The Bt11 event codes for the Cry1Ab protein with the e-35S promoter (Novartis Seeds, Gorden Valley, MN). Like Bt11, Event 176 also codes for the Cry1Ab protein but is different in that it has a PEP pollen promoter (Mycogen Seeds, San Diego, CA).

Forty-eight dryland plots (two $6.10 \mathrm{~m}$ long rows spaced $0.76 \mathrm{~m}$ apart, planted at 41,975 kernels/ha) at each site were allocated to 12 treatment combinations in a 3 by 4 factorial split-plot design with four replications. Maize hybrid served as the main plot factor, while European corn borer control measure served as the subplot factor.

Plots were subjected to 1 of 4 European corn borer control regimes: control (non$B t$ maize isoline with no control measures taken); formulated Bt (Dipel 10G @ 0.921 $\mathrm{kg}(\mathrm{Al}) / \mathrm{ha}$ for first generation O. nubilalis, Dipel ES @ 101.67ml (Al)/ha for secondgeneration 0 . nubilalis); permethrin (Pounce $1.5 \mathrm{G} @ 0.18 \mathrm{~kg}(\mathrm{Al}) / \mathrm{ha}$ for firstgeneration $O$. nubilalis, Pounce 3.2EC @ $18.59 \mathrm{ml}(\mathrm{Al}) /$ ha for second-generation); and transgenic $B t$ maize hybrids. First-generation insecticide treatments were applied approximately $14 \mathrm{~d}$ after initiation of egg laying (2 July 1997 at both locations) using a hand-held granular spreader. Insecticide treatments for second-generation control were applied when approximately $50 \%$ of the egg masses had reached blackhead stage during the peak egg laying period (12 August 1997 at Saunders Co., 13 August 1997 at Dixon Co.).

Ostrinia nubilalis control efficacy was measured for 10 plants in each treatment combination. The following parameters were measured: first generation leaf feeding ratings (Guthrie 1960), tunnels/plant, length of tunneling/plant, larvae/plant, percent ear shank damage, percent dropped ears, percent lodged plants, and grain yield. All parameters except leaf feeding ratings were measured at harvest. Data were tested by analysis of variance (ANOVA) for main, subplot, and interaction effects (SAS Institute 1996). Arcsine transformation was used to normalize percentage data before ANOVA was calculated. When the effect of a European corn borer control measure was significant $(P<0.05)$, means for each subplot treatment were separated using Fisher's protected least significant difference method (LSD; $P<0.05$ ).

\section{Results and Discussion}

First generation European corn borer. At both sites, leaf-feeding ratings were low across all $O$. nubilalis control treatments, with only minor significant differences at the Dixon Co. site. Thus, we have omitted these data from this paper. Low damage readings most likely can be attributed to gravid $O$. nubilalis females being attracted to earlier planted maize in adjacent fields (Mason et al. 1996).

Second generation European corn borer. All control measures significantly reduced $O$. nubilalis damage in terms of tunnels per plant, length of tunneling and larvae per plant when compared to the controls within hybrid groupings at both locations (Figs. 1-3). In general, the following hierarchy in terms of degree of control was observed: transgenic Bt maize > permethrin > formulated Bt > control. However, the permethrin treated hybrids were usually not significantly different from the DEKALB (DBT418) and Mycogen (176) Bt maize hybrids. The Novartis Bt hybrids (Bt 11) always had the lowest amount of damage and fewest larvae recovered.

Transgenic and permethrin treated hybrids had significantly fewer ear shanks damaged than the controls at the Saunders County location (Fig. 4). Formulated Bt treated hybrids significantly reduced ear shank damage over the controls in the 


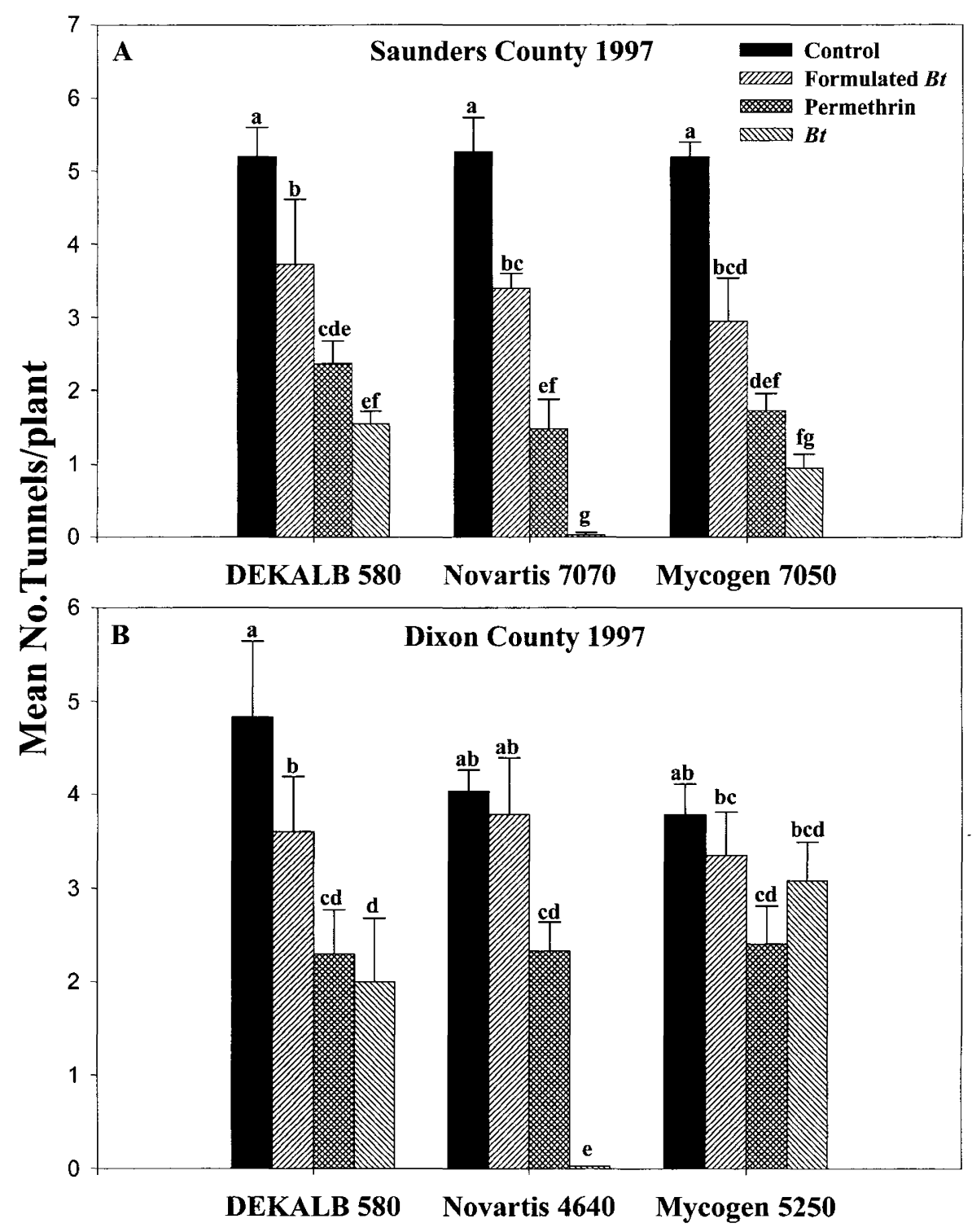

Fig. 1. Mean number of $O$. nubilalis tunnels per plant with various treatments in different maize hybrids at Saunders (A) and Dixon Co. (B) NE, 1997. Columns with a common letter are not significantly different at $P<0.05$ by Fisher's protected LSD. 


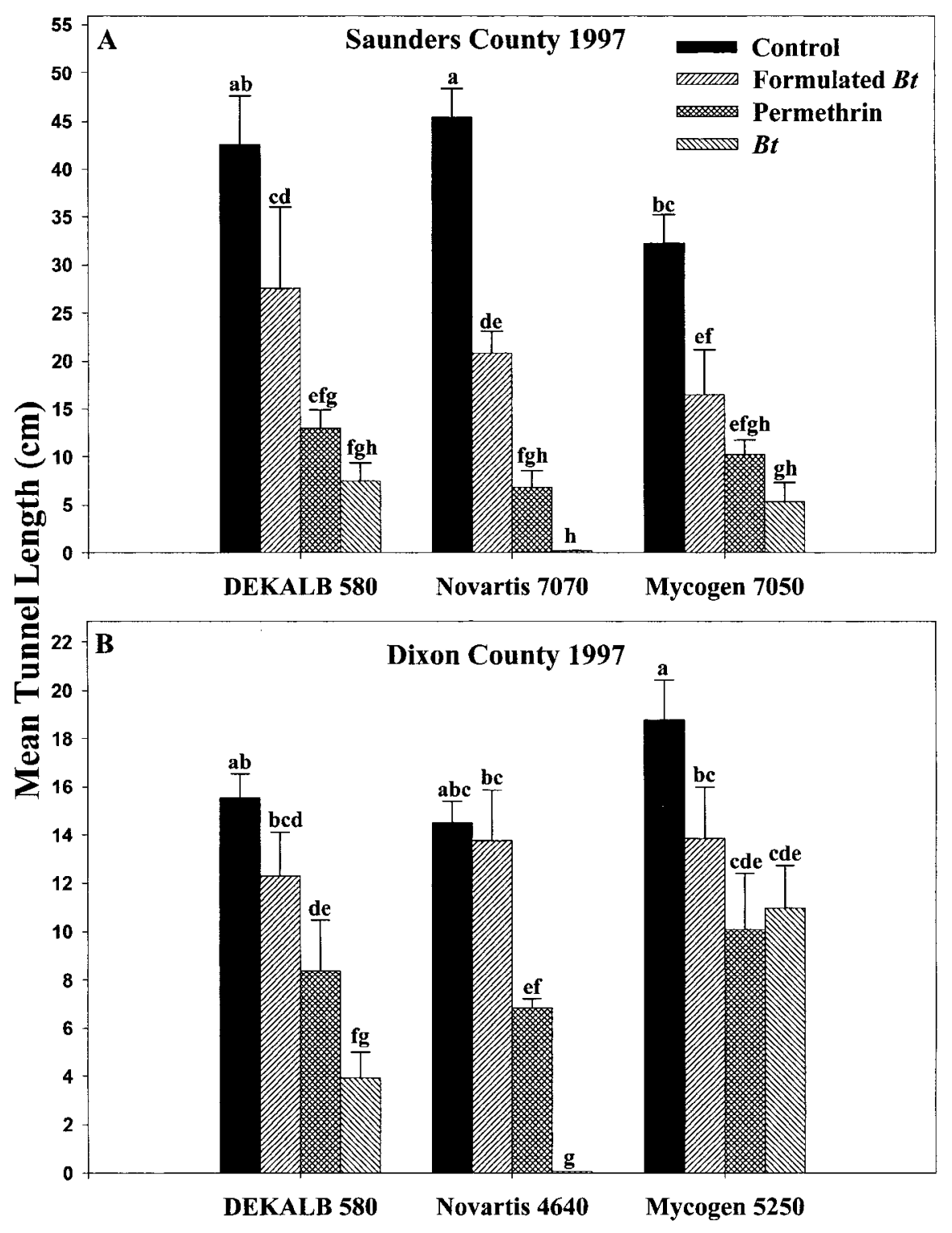

Fig. 2. Mean $O$. nubilalis tunnel length $(\mathrm{cm})$ per plant with various treatments in different maize hybrids at Saunders (A) and Dixon Co. (B) NE, 1997. Columns with a common letter are not significantly different at $P<0.05$ by Fisher's protected LSD. 


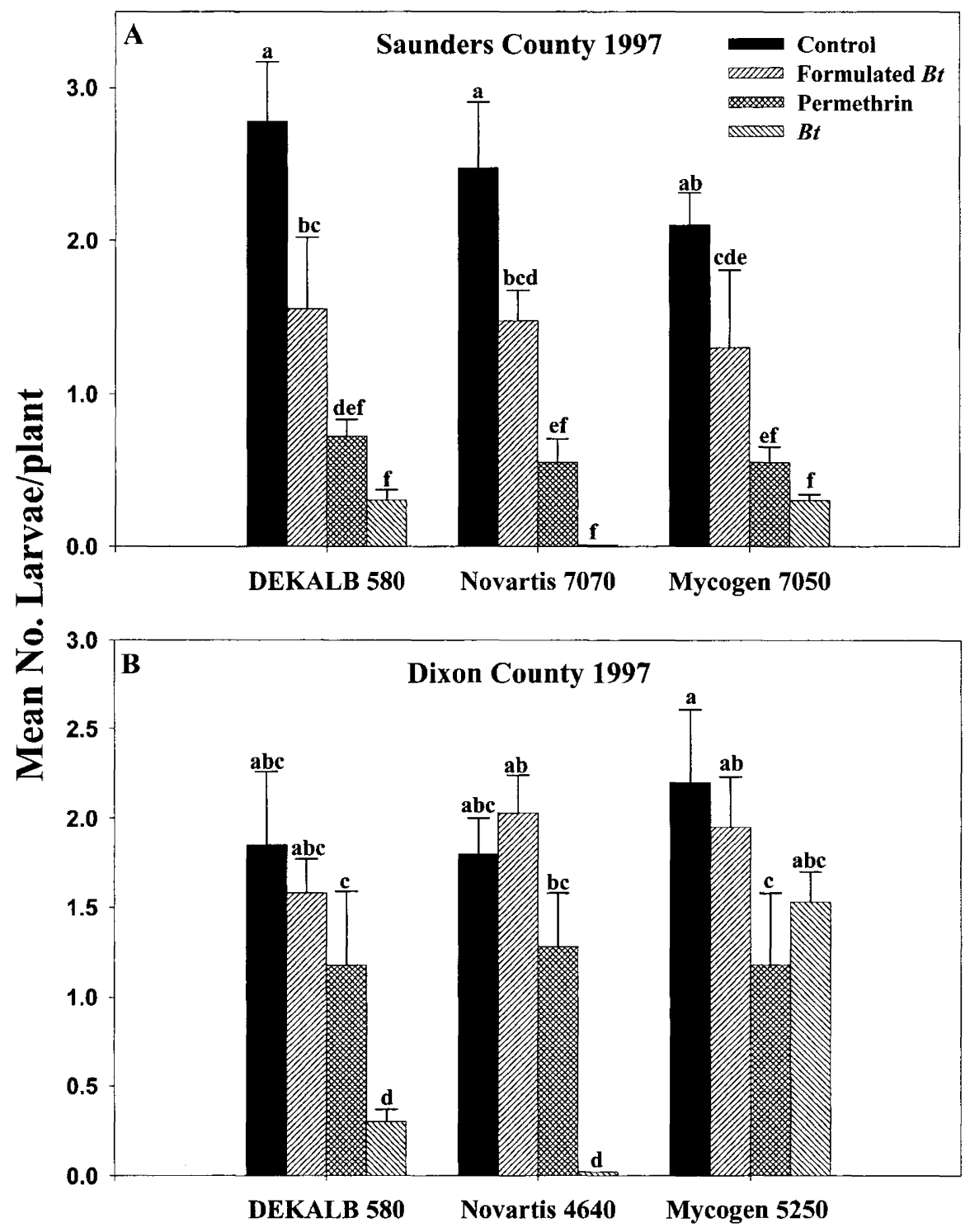

Fig. 3. Mean number of $O$. nubilalis larvae per plant at harvest with various treatments in different maize hybrids at Saunders (A) and Dixon Co. (B) NE, 1997. Columns with a common letter are not significantly different at $P<0.05$ by Fisher's protected LSD. 


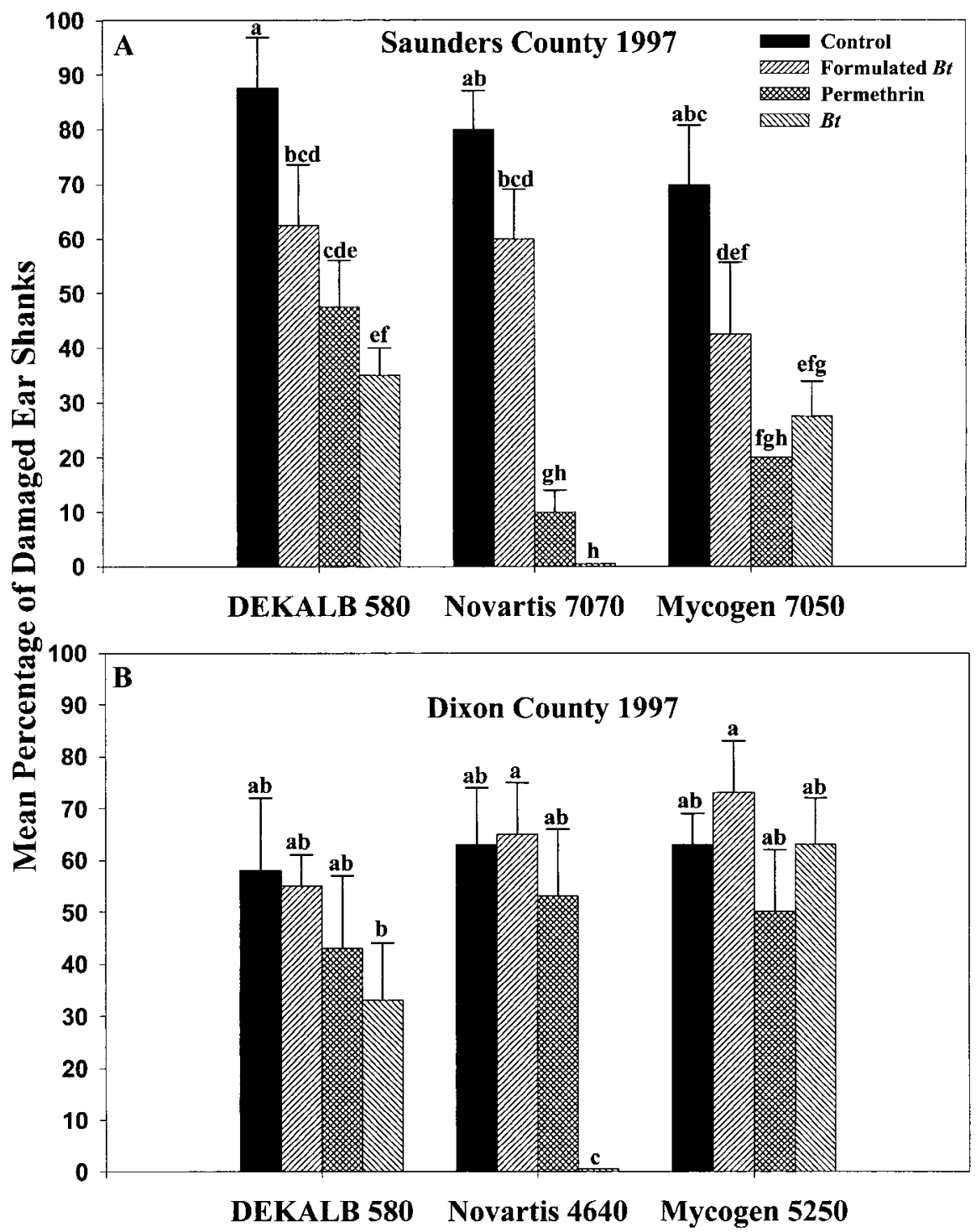

Fig. 4. Mean percentage of $O$. nubilalis damaged ear shanks at harvest with various treatments in different maize hybrids at Saunders (A) and Dixon Co. (B) NE, 1997. Columns with a common letter are not significantly different at $P<0.05$ by Fisher's protected LSD.

DEKALB 580 and Mycogen 7050 groupings. Only the Novartis $4640 B$ thybrid significantly reduced ear shank damage at the Dixon Co. site.

At Saunders Co., Mycogen 7050 treated with permethrin, formulated Bt, or transgenic $B t$ had significantly fewer dropped ears than the control (Table 1). All other 
within-hybrid comparisons for dropped ears (Table 1), and lodged plants were not significantly different at both sites.

Transgenic $B t$ maize hybrids generally had significantly higher yields than the controls at both sites (Fig. 5). At the Saunders Co. site the Mycogen 7050Bt was an exception although it had a greater overall mean than its control isoline. Permethrin treated maize hybrids had higher overall mean yields within their hybrid groups than the untreated checks; however, only the Novartis 7070 and DEKALB 580 hybrids at Saunders Co. had significantly greater yields than their control isolines. Likewise, except for Mycogen 5250 + permethrin compared with Mycogen 2598Bt in Dixon Co., maize hybrids isolines + permethrin had yields equal to the transgenic maize hybrids within their hybrid groupings. At the Saunders Co. site, the Novartis 7070 maize hybrid + permethrin had a significantly higher yield the same hybrid treated with formulated $B t$, which was the only within hybrid example of permethrin significantly protecting yield more than formulated Bt. The DEKALB 580 hybrid + formulated Bt was the only example of significant protection of yield greater than the control within a maize hybrid grouping.

Overall, the transgenic $B t$ maize hybrids provided better $O$. nubilalis control than the other treatments. However, the DEKALB and Mycogen hybrids that contained $B t$ toxins, which do not offer season-long protection, were similar in efficacy to permethrin-treated plots. This was apparently due to the degradation or reduced synthesis of active ingredients that control O. nubilalis (Onstad and Gould 1998). Because late-season $O$. nubilalis moth flights were still occurring during the apparent degradation period, measurable damage occurred in these plots. Plots treated with formulated $B t$ clearly had an earlier breakdown of active ingredients and became susceptible to second-generation $O$. nubilalis damage before transgenic and permethrin treated plots. Thus, plots treated with formulated $B t$ were generally not as efficacious against $O$. nubilalis.

Table 1. Percentage of dropped ears due to European corn borer feeding at Saunders and Dixon Counties in 1997

\begin{tabular}{lcccc}
\hline \hline Maize hybrid & Control & DiPel & Permethrin & Transgenic Bt \\
\hline \multicolumn{5}{c}{ Saunders County } \\
DEKALB 580 & $1.64 \pm 0.95 \mathrm{~b}$ & $3.74 \pm 2.26 \mathrm{~b}$ & $1.57 \pm 0.91 \mathrm{~b}$ & $3.43 \pm 1.37 \mathrm{~b}$ \\
Novartis 7070 & $1.91 \pm 1.22 \mathrm{~b}$ & $3.71 \pm 1.44 \mathrm{~b}$ & $1.94 \pm 0.65 \mathrm{~b}$ & $0.00 \pm 0.00 \mathrm{~b}$ \\
Mycogen 7050 & $11.98 \pm 3.62 \mathrm{a}$ & $2.68 \pm 1.71 \mathrm{~b}$ & $1.56 \pm 1.56 \mathrm{~b}$ & $0.00 \pm 0.00 \mathrm{~b}$ \\
& & Dixon County & & \\
DEKALB 580 & $0.00 \pm 0.00 \mathrm{NS}$ & $0.00 \pm 0.00 \mathrm{NS}$ & $0.00 \pm 0.00 \mathrm{NS}$ & $1.00 \pm 0.00 \mathrm{NS}$ \\
Novartis 4640 & $0.78 \pm 0.78 \mathrm{NS}$ & $1.43 \pm 0.83 \mathrm{NS}$ & $0.00 \pm 0.00 \mathrm{NS}$ & $0.00 \pm 0.00 \mathrm{NS}$ \\
Mycogen 5250 & $1.56 \pm 1.56 \mathrm{NS}$ & $2.94 \pm 1.11 \mathrm{NS}$ & $0.68 \pm 0.68 \mathrm{NS}$ & $0.00 \pm 0.00 \mathrm{NS}$ \\
\hline
\end{tabular}

Means follow by the same letters in each location grouping are not significantly different; Fisher's protected LSD; $(P=0.05)$

* Mycogen $2598 B t$ 

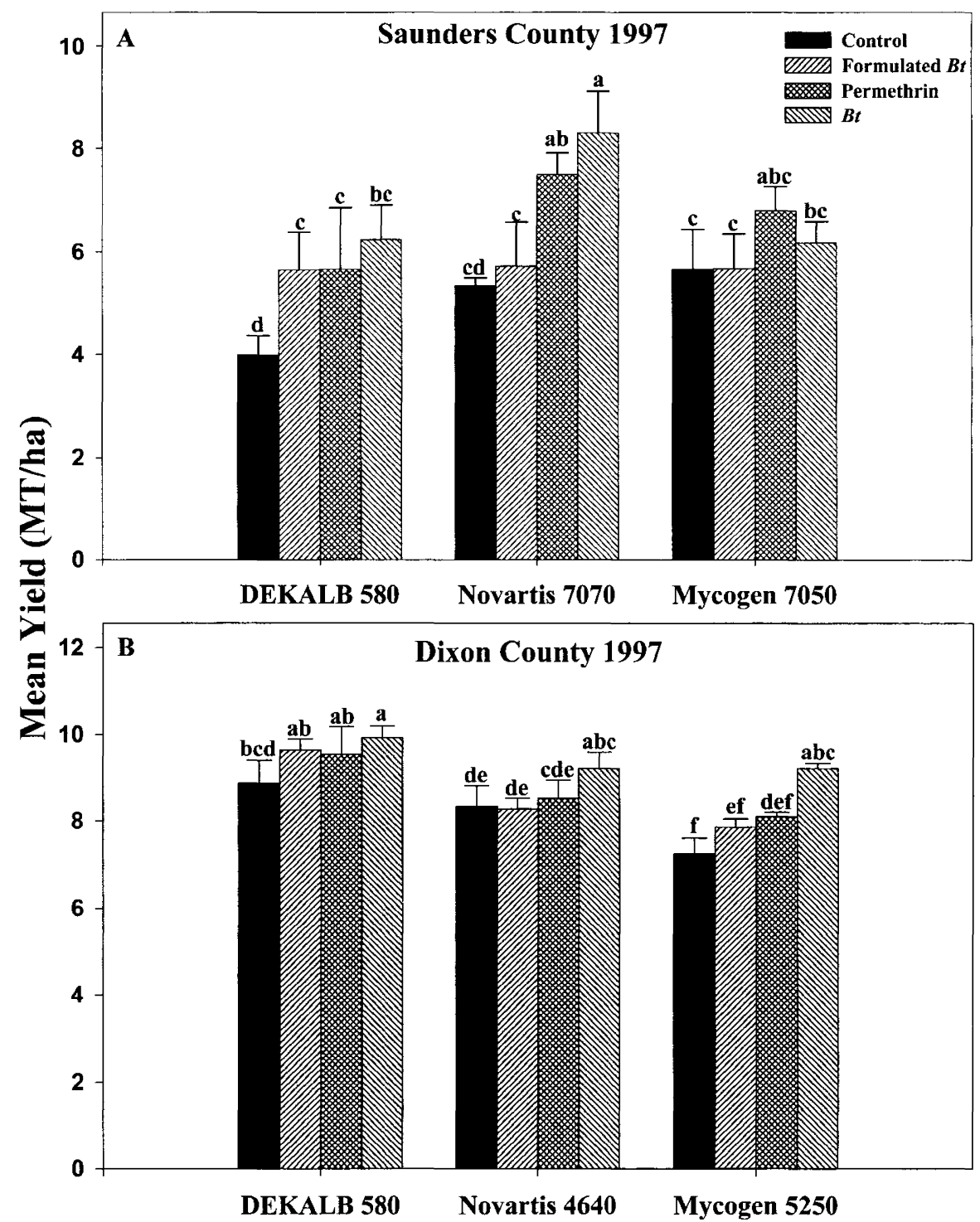

Fig. 5. Mean grain yield in metric tons per hectare with various treatments in different maize hybrids at Saunders (A) and Dixon Co. (B) NE, 1997. Columns with a common letter are not significantly different at $P<0.05$ by test Fisher's protected LSD.

Because the Mycogen and DEKALB transgenic hybrids performed similarly to the permethrin treated hybrids, an interesting question arises. Should maize producers invest in a prophylactic control and buy Bt maize seed, or should they treat their fields with permethrin or other topically applied insecticides based on economic thresholds? 
This study showed the level of effectiveness of a few of the current control strategies for $O$. nubilalis. The next step is to evaluate advantages and disadvantages for each control strategy including the effect on natural enemies and human health and make control recommendations based on those evaluations.

\section{Acknowledgments}

We thank J. Echtenkkamp for assistance in data collection. This research was supported by USDA CSREES/NAPIAP Grant No. 95-EPIX-1-0235. We also thank B. D. Siegfried and S. D. Danielson, Department of Entomology, University of Nebraska-Lincoln for their critical review of this manuscript. This article is published as paper No. 12575, Journal Series, Nebraska Agricultural Research Division and contribution No. 1022, Department of Entomology, Institute of Agriculture and Natural Resources, University of Nebraska-Lincoln.

\section{References Cited}

Ayappath, R., J. F. Witkowski and L. G. Higley. 1996. Population changes of spider mites (Acari: Tetranychidae) following insecticide applications in corn. Environ. Entomol. 25: 933937.

Bartels, D. W. and W. D. Hutchison. 1995. On-farm efficacy of aerially applied Bacillus thuringiensis for European corn borer (Lepidoptera: Pyralidae) and corn earworm (Lepidoptera: Noctuidae) control in sweet corn. J. Econ. Entomol. 88: 380-386.

Bergvinson, D., M. Willcox, D. Hoisington and W. A. Overholt. 1997. Efficacy and deployment of transgenic plants for stemborer management. Insect Sci. and its Applic. 17: 157-167.

Bolin, P. C., W. D. Hutchison and D. W. Davis. 1996. Resistant hybrids and Bacillus thuringiensis for management of European corn borer (Lepidoptera: Pyralidae) in sweet corn. J. Econ. Entomol. 89: 82-91.

Bullock, W. O., and C. Sollod. 1996. The business side of Bt products: a market analysis. In Information Systems for Biotechnology, NBIAP News Report. World Wide Web (http:// www.nbiap.vt.edu/news/specials/news95.dec.html).

Caprio, M. A., R. G. Luttrell, S. MacIntosh, M. E. Rice, B. Siegfried, J. F. Witkowski, J. Van Duyn, D. Moellenbeck, E. Sachs and J. Stein. 1999. An evaluation of insect resistance management in Bt field corn: Report of an expert panel. International Life Sciences Institute, Washington D.C.

Guthrie, W. D., F. F. Dicke and C. R. Neiswander. 1960. Leaf and sheath feeding resistance to the European corn borer in eight inbred lines of dent corn. Ohio Agric. Exp. Stn. Bull. 860.

Koziel, M G., G. L. Beland, C. Bowman, N. B. Carozzi, R. Crenshaw, L. Crossland, J. Dawson, N. Desai, M. Hill, S. Kadwell, K. Launis, K. Lewis, D. Maddox, K. McPherson, M. R. Meghji, E. Merlin, R. Rhodes, G. W. Warren, M. Wright and S. V. Evola. 1993. Field performance of transgenic maize plants expressing an insecticidal protein derived from Bacillus thuringiensis. BioTechnology 11: 194-200.

Mason, C. E., M. E. Rice, D. D. Calvin, J. W. Van Duyn, W. B. Showers, W. D. Hutchinson, J. F. Witkowski, R. A. Higgins, D. W. Onstad and G. P. Dively. 1996. European corn borer ecology and management. North Central Regional Extension Publication No. 327.

Onstad, D. W., and F. Gould. 1998. Modeling the dynamics of adaptation to transgenic maize by European corn borer (Lepidoptera: Pyralidae). J. Econ. Entomol. 91: 585-593.

Ostlie, K. R., W. D. Hutchinson, and R. L. Hellmich. 1997. Bt corn and European corn borer. North Central Regional Publication No. 602. University of Minnesota, St. Paul, MN.

Rinkleff, J. H., W. D. Hutchison, C. D. Campbell, P. C. Bolin and D. W. Bartels. 1995. Insecticide toxicity in European corn borer (Lepidoptera: Pyralidae): Ovicidal activity and residual mortality to neonates. J. Econ. Entomol. 88: 246-253.

SAS Institute. 1996. SAS/STAT user's guide, version $6.12,4^{\text {th }}$ ed., SAS Institute, Cary, NC. 
Tally S. 1998. Agriculture's new horizon: Biotechnology's course moves into the mainstream. Purdue Agricultures Magazine Fall 1998 2: 12-17.

Williams, W. P., P. M. Buckley, J. B. Sagers and J. A. Hanten. 1998. Evaluation of transgenic corn for resistance to corn earworm (Lepidoptera: Noctuidae), fall armyworm (Lepidoptera: Noctuidae), and southwestern corn borer (Lepidoptera: Crambidae) in a laboratory bioassay. J. Agric. Entomol. 15: 105-112.

Wright, R. J., S. D. Danielson, J. F. Witkowski, G. L. Hein, J. B. Campbell, K. J. Jarvi, R. C. Seymour and J. A. Kalisch. 1994. Insect Management Guide for Nebraska Corn and Sorghum. Nebraska Cooperative Extension EC 94-1509-D. 